\title{
Correction to: Toward a comparative anthropology of activism: activist identity formations in Germany and Uganda
}

\section{Žiga Podgornik-Jakil ${ }^{1}$. Jonas Bens ${ }^{1}$}

Published online: 21 July 2021

(c) Springer Nature B.V. 2021

\section{Correction to: Dialectical Anthropology https://doi.org/10.1007/s10624-021-09628-3}

After publication of this paper, the authors determined that there were omitted anonymized references.

The original article has been corrected.

Publisher's note Springer Nature remains neutral with regard to jurisdictional claims in published maps and institutional affiliations.

The original article can be found online at https://doi.org/10.1007/s10624-021-09628-3.

\footnotetext{
Žiga Podgornik-Jakil
} zigajakil@gmail.com

1 Department of Social and Cultural Anthropology, Freie Universitat, Berlin, Germany 